\author{
A VARIATIONAL TECHNIQUE FOR THERMODYNAMICS \\ OF LIQUID $K_{1-X} R b_{X}$ ALLOYS \\ (D) Rajesh C. Malan ${ }^{\mathrm{a}, *}$, (D)Aditya M. Vora ${ }^{\mathrm{b}}$ \\ ${ }^{a}$ Applied Science and Humanities Department, Government Engineering College, Valsad-396001, Gujarat, India \\ ${ }^{b}$ Department of Physics, University School of Sciences, Gujarat University, Ahmedabad-380009, India \\ *Corresponding Author: rcmgecv@gmail.com \\ Received February 1, 2021; revised April 9, 2021; accepted April 14, 2021
}

Liquid $K_{1-X} R b_{X}$ binary alloys with various thermodynamical proportions of participating elements are investigated. The properties of thermodynamic interest are included in the study. The internal energy $\left(F_{\text {int }}\right)$, Helmholtz free enrgy $\left(F_{H}\right)$ and the entropy $(S)$ have been calculated in a concentration range from $X=0.0$ to $X=1.0$ increasing in a step of 0.1 in the present work. Apart from the internal energy $\left(F_{\text {int }}\right)$, various contributions to this energy are also calculated and separately depicted in the present article. A variational approach has been adopted for the present calculation. A single potential with a set of two parameters is used for the calculation of all properties of the alloys. Static Hartree local field function $(\mathrm{H})$ is used to consider screening effect. Various local field correction functions are used to take into account the exchange and correlation effect. Comparison with experimental data at some concentration shows the good agreement with the presently obtained data. With the help of current results, the applied model potential found very suitable with individual parameters for thermodynamical study. As the present results provide the data even where minimum availability of the experimental findings, it can serve as a data base for the future calculation which deals with thermodynamics of the liquid alloys. Present results allow one to get proportion based tuned properties of the $K_{1-X} R b_{X}$ for different requirements.

KEYWORDS: thermodynamical properties, liquid alkali alloy, pseudopotential theory, variational approach, Gibbs-Bogoliubov inequality.

The thermodynamic properties of the metals as well as alloys are of the prime importance, particularly when they are used in industry at a large scale productions or manufacturing purpose. The exact information at atomic level regarding the all aspects from thermodynamic behaviour has a great significance in this field. The thermodynamic study is possible in two alternate ways: a) experimental and b) theoretical. The former is the expensive way while the other required a dip understanding the formulation of the thermodynamic problems in terms of mathematical models. There have been lot of theoretical study carried out by various methods for thermodynamic study of liquid metals and alloys [2-7]. The pseudopotential method is the one of the successful method to demonstrate almost all type of properties in solid as well as liquid form of the matter.

The alkali group involves the metals which are having their melting points very near or just above the room temperature. This may create rapid phase change of the metals from liquid to solid or vice versa. Thus the applications of the liquid alkali metal and their binary alloys seek the information in liquid phase also. The present article involves thermodynamic study of one of the alkali-alkali binary alloy $K_{1-X} R b_{X}$ using Gibbs-Bogoliubov inequality [8]. The internal energy $\left(F_{\text {int }}\right)$ and some contributions toward it, Helmholtz free energy $\left(F_{H}\right)$ and the various types of entropy of the binary system are obtained using the individual set of the parameters of the model potential suggested by Fiolhais et al [1]. The comparison with the others results are shown in the tabular format for each component in the next part of the manuscript.

\title{
THEORETICAL DETAIL
}

The present work extends the computation to the system of binary alkali alloy $N a_{1-X} K_{X}$. According to which for the binary system of alloy, The Helmholtz free energy $\left(F_{H}\right)$ is obtained from the equation [4], [9],

$$
F_{H}=F_{p s}+F_{i i i}
$$

Where $F_{p s}$ is the averaged effective potential of the system and it can be given as [4], [9] $]^{4-6}$,

$$
F_{p s}=F_{g}+F_{M}+F_{i}+F_{i i}
$$

It includes the free energy of the electron gas $F_{g}$ and first and second order perturbation parts $F_{i}$ and $F_{i i}$ respectively. Free energy of the electron gas $F_{g}$ can be given as [4], [9],

$$
F_{g}=\left[\frac{3}{10} k_{f}^{3}-\frac{3}{10} k_{f}+E_{c}-\frac{1}{2} \gamma_{g} T^{2}\right]
$$

where $E_{c}$ is correlation energy contribution and $\gamma_{g}$ is low temperature specific heat constant. The second term in equation (1) i.e. the free energy per particle $\left(F_{i i i}\right)$ of the binary mixture can be expressed in terms of entropy $\left(S_{m i x}\right)$ as [4], [9], 


$$
\begin{gathered}
F_{i i i}=\frac{3}{2} K T-T S_{\text {mix }}, \\
S_{\text {mix }}=S_{g a s}+S_{c}+S_{\eta+} S_{\sigma},
\end{gathered}
$$

where $S_{\text {gas }}$ represents the gas term, $S_{c}$ is the ideal entropy of mixing, $S_{\eta}$ corresponds to packing density $(\eta)$ and $S_{\sigma}$ arise due to the difference in hard diameters of participating elements of an alloy.

The internal energy $\left(F_{\text {int }}\right)$ can be given as,

$$
F_{\text {int }}=\frac{3}{2} k_{B} T+F_{e g}+F_{\mathrm{i}}+F_{\mathrm{ii}}+F_{M}
$$

\section{RESULTS AND DISCUSSION}

Table 1 gives the input parameters and constants used for the present calculations including potential parameters. As it is one of the key goals of the article i.e. to test parameters of Fiolhais et al. [1] in its original form for the study of $\mathrm{K}-\mathrm{Rb}$ alloys, no change in the parameters of potential has been made.

Table 1. Potential parameters and other constants used for computation

\begin{tabular}{|c|c|c|c|c|c|}
\hline Metal & $\boldsymbol{Z}$ & $\boldsymbol{\Omega}(\mathbf{a u})$ & $\boldsymbol{\eta}$ & $\boldsymbol{\alpha}[\mathbf{1}]$ & $\boldsymbol{R}[\mathbf{1}]$ \\
\hline $\mathrm{K}$ & 1 & 535.33 & 0.46 & 3.349 & 0.679 \\
\hline $\mathrm{Rb}$ & 1 & 656.17 & 0.43 & 3.228 & 0.755 \\
\hline
\end{tabular}

To estimate the screening effect over the bare ion potential the Hartree local field correction function $(\mathrm{H})[10]$ is used. The other local field correction functions used over the bare ion potentials are the functions suggested by HubbardSham (HS) [11], [12], Vashishtha-Shingwi (VS) [13], Taylor (T) [14], Sarkar et al.(S) [15], Ichimaru-Utsumi (IU) [16] and Farid et al. (F) [17] and Nagy (N) [18].

Table 2 shows the potential independent contributions $\left(F_{i}\right),\left(F_{i i i}\right)$ and $\left(F_{g}\right)$ to total free energy. It can be seen from the Table 2 that except $F_{i i i}$, all are having negative contribution. The present results for $F_{g}$ are compared with others results [19]. An excellent agreement of present results for $F_{g}$ is obtained with compared results [19]. The present results of $F_{i}$ and $F_{i i}$ are also compared with the results of others [19].

Table 2. Various contributions to internal energy $\left(F_{\text {int }}\right) * 10^{-3}$ au

\begin{tabular}{|c|c|c|c|c|c|c|c|}
\hline $\mathbf{X}$ & $\boldsymbol{F}_{\boldsymbol{g}}$ & Others [19] & $\boldsymbol{F}_{\boldsymbol{i}}$ & Others [19] & $\boldsymbol{F}_{\boldsymbol{m}}$ & Others [19] & $\boldsymbol{F}_{\boldsymbol{i i i}}$ \\
\hline 0.0 & -79.90 & - & 79.97 & - & -209.48 & - & -8.52 \\
\hline 0.1 & -79.77 & -79.81 & 71.43 & 100.28 & -205.78 & -212.51 & -8.69 \\
\hline 0.2 & -79.63 & -79.66 & 74.64 & 98.24 & -209.80 & -210.26 & -8.85 \\
\hline 0.3 & -79.49 & -79.52 & 77.73 & 96.28 & -214.99 & -208.12 & -9.02 \\
\hline 0.4 & -79.36 & -79.37 & 80.70 & 94.41 & -218.63 & -206.15 & -9.18 \\
\hline 0.5 & -79.22 & -79.23 & 83.55 & 92.61 & -219.50 & -204.19 & -9.34 \\
\hline 0.6 & -79.08 & -79.08 & 86.30 & 90.88 & -217.21 & -202.31 & -9.50 \\
\hline 0.7 & -78.94 & -78.93 & 88.95 & 89.22 & -212.17 & -200.57 & -9.66 \\
\hline 0.8 & -78.80 & -78.78 & 91.50 & 87.62 & -205.57 & -199.14 & -9.82 \\
\hline 0.9 & -78.66 & -78.64 & 93.96 & 86.08 & -199.76 & -197.42 & -9.98 \\
\hline 1.0 & -78.52 & - & 96.34 & - & -200.21 & - & -10.14 \\
\hline
\end{tabular}

The reason for deviation between present results and others results [19] for $F_{i}$ lies in the mathematical approach of variational method. According to variational approach, a first guess for the real function is made, which will then constrained by the boundary conditions to minimize the deviation between actual and the first guess function. The perturbation part is added to get the maximum closest result to the actual one. The deviation between the present values of $F_{i}$ and that of the others is just the difference between the perturbation parts of both the results. Which has no physical significant. Hence, the deviation is not affecting on the final results of the internal energy $\left(F_{\text {int }}\right)$. Similar logic can be applied to the calculation of $F_{i i}$ also.

Table 3 shows $F_{i i}$ obtained by application of various local field correction functions. The results obtained for $\mathrm{N}$-function [18] are maximum whereas it is minimum due to the correction function Hartree (H) [10]. 
Table 3. $\left(F_{i i} * 10^{-3}\right)$ au

\begin{tabular}{|c|c|c|c|c|c|c|c|c|c|}
\hline $\mathbf{X}$ & $\mathbf{H}$ & $\mathbf{H S}$ & $\mathbf{V S}$ & $\mathbf{T}$ & $\mathbf{S}$ & $\mathbf{I U}$ & $\mathbf{F}$ & $\mathbf{N}$ & Others [19] \\
\hline 0.0 & -14.58 & -14.12 & -13.68 & -13.52 & -13.89 & -13.33 & -13.31 & -11.88 & - \\
\hline 0.1 & -29.36 & -28.70 & -28.10 & -27.92 & -28.40 & -27.66 & -27.65 & -25.21 & -2.68 \\
\hline 0.2 & -26.51 & -25.90 & -25.34 & -25.16 & -25.62 & -24.92 & -24.90 & -22.68 & -2.85 \\
\hline 0.3 & -18.80 & -18.31 & -17.85 & -17.69 & -18.07 & -17.49 & -17.48 & -15.83 & -3.01 \\
\hline 0.4 & -11.72 & -11.37 & -11.01 & -10.87 & -11.18 & -10.71 & -10.70 & -9.60 & -3.08 \\
\hline 0.5 & -7.84 & -7.57 & -7.28 & -7.15 & -7.41 & -7.03 & -7.02 & -6.24 & -3.22 \\
\hline 0.6 & -8.21 & -7.95 & -7.68 & -7.57 & -7.81 & -7.45 & -7.44 & -6.66 & -3.37 \\
\hline 0.7 & -12.33 & -12.01 & -11.70 & -11.59 & -11.85 & -11.46 & -11.45 & -10.35 & -3.44 \\
\hline 0.8 & -18.28 & -17.86 & -17.47 & -17.35 & -17.66 & -17.18 & -17.17 & -15.56 & -3.27 \\
\hline 0.9 & -22.07 & -21.57 & -21.10 & -20.96 & -21.33 & -20.76 & -20.75 & -18.76 & -3.46 \\
\hline 1.0 & -14.05 & -13.63 & -13.22 & -13.08 & -13.42 & -12.89 & -12.88 & -11.41 & - \\
\hline
\end{tabular}

Figure 1 shows the various types of entropy contributions. The ideal entropy of mixing $S_{c}$ is found very low (almost zero) for each of the concentrations. The ideal gas entropy $\left(S_{g}\right)$ gives the maximum contribution for entropy $\left(S_{\text {mix }}\right)$.

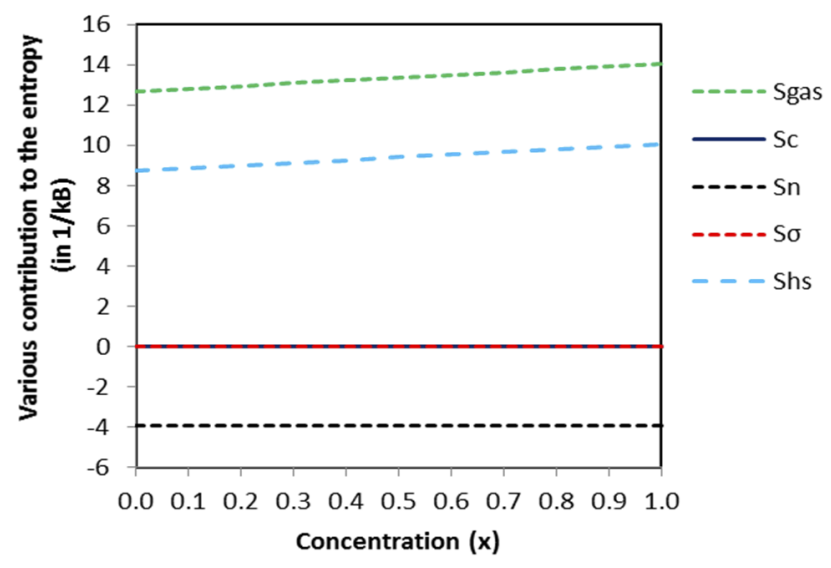

Figure 1. Entropy contributions

The internal energy $\left(F_{\text {int }}\right)$ of the present calculation has been be compared with previously published results of Vora [2] and Thakor [19] as well as with the experimental results [5] as shown in Table 4. The internal energy $\left(F_{\text {int }}\right)$ at higher concentration value $(\mathrm{X})$ is found in a very good agreement with the experimental results [5] and the results of others [2], [19].

Table 4. Internal Energy $\left(-F_{\text {int }} * 10^{-3}\right)$ au

\begin{tabular}{|c|c|c|c|c|c|c|c|c|c|c|}
\hline $\mathbf{X}$ & $\mathbf{H}$ & $\mathbf{H S}$ & $\mathbf{V S}$ & $\mathbf{T}$ & $\mathbf{S}$ & $\mathbf{I U}$ & $\mathbf{F}$ & $\mathbf{N}$ & Others [2], [19] & Exp [5] \\
\hline 0.00 & 266.57 & 266.11 & 265.67 & 265.52 & 265.88 & 265.32 & 265.31 & 263.88 & 260.46 & 194 \\
\hline 0.10 & 208.50 & 207.84 & 207.24 & 207.06 & 207.54 & 206.80 & 206.79 & 204.35 & 193.11 & - \\
\hline 0.20 & 200.06 & 199.44 & 198.88 & 198.70 & 199.16 & 198.46 & 198.45 & 196.23 & 192.94 & - \\
\hline 0.30 & 186.92 & 186.44 & 185.98 & 185.81 & 186.20 & 185.62 & 185.60 & 183.96 & 192.78 & - \\
\hline 0.40 & 174.64 & 174.28 & 173.93 & 173.78 & 174.09 & 173.63 & 173.62 & 172.52 & 192.62 & - \\
\hline 0.50 & 165.79 & 165.51 & 165.22 & 165.10 & 165.36 & 164.98 & 164.96 & 164.19 & 192.47 & - \\
\hline 0.60 & 161.44 & 161.18 & 160.91 & 160.79 & 161.03 & 160.68 & 160.67 & 159.89 & 192.33 & - \\
\hline 0.70 & 161.11 & 160.80 & 160.49 & 160.37 & 160.63 & 160.24 & 160.23 & 159.13 & 192.19 & - \\
\hline 0.80 & 162.91 & 162.49 & 162.10 & 161.98 & 162.29 & 161.81 & 161.80 & 160.19 & 192.06 & - \\
\hline 0.90 & 162.85 & 162.35 & 161.88 & 161.74 & 162.11 & 161.54 & 161.53 & 159.54 & 191.93 & - \\
\hline 1.00 & 151.29 & 150.87 & 150.46 & 150.32 & 150.66 & 150.14 & 150.13 & 148.65 & 249.94 & 180 \\
\hline
\end{tabular}


The agreement with the results of Thakor [19] for internal energy $\left(F_{\text {int }}\right)$ suggests that there is no effect of deviation between the presently calculated results of $F_{i}$ and the $F_{i}$ calculated by Thakor [19]. Similar is the case with the presently calculated $F_{i i}$ and the $F_{i i}$ calculated by Thakor [19]. The Helmholtz free energy $\left(F_{H}\right)$ shown in Table 5.

Table 5. Helmholtz free energy $\left(-F_{H} * 10^{-3}\right)$ au

\begin{tabular}{|c|c|c|c|c|c|c|c|c|c|c|}
\hline $\mathbf{X}$ & $\mathbf{H}$ & $\mathbf{H S}$ & $\mathbf{V S}$ & $\mathbf{T}$ & $\mathbf{S}$ & $\mathbf{I U}$ & $\mathbf{F}$ & $\mathbf{N}$ & Others [2], [19] & $\mathbf{E x p}[5]$ \\
\hline 0.0 & 311.53 & 311.07 & 310.63 & 310.47 & 310.84 & 310.27 & 310.26 & 308.83 & 270.70 & 199.10 \\
\hline 0.1 & 252.17 & 251.50 & 250.91 & 250.72 & 251.20 & 250.46 & 250.45 & 248.02 & 212.08 & 198.47 \\
\hline 0.2 & 250.15 & 249.54 & 248.98 & 248.80 & 249.26 & 248.56 & 248.54 & 246.32 & 212.53 & 197.68 \\
\hline 0.3 & 244.56 & 244.08 & 243.62 & 243.45 & 243.84 & 243.26 & 243.24 & 241.60 & 212.83 & 196.78 \\
\hline 0.4 & 238.19 & 237.83 & 237.48 & 237.33 & 237.64 & 237.18 & 237.17 & 236.07 & 213.02 & 195.41 \\
\hline 0.5 & 232.35 & 232.07 & 231.79 & 231.66 & 231.92 & 231.54 & 231.53 & 230.75 & 213.10 & 193.33 \\
\hline 0.6 & 227.70 & 227.44 & 227.17 & 227.06 & 227.29 & 226.94 & 226.93 & 226.15 & 213.10 & 192.19 \\
\hline 0.7 & 224.15 & 223.83 & 223.52 & 223.41 & 223.67 & 223.28 & 223.27 & 222.17 & 213.00 & 192.11 \\
\hline 0.8 & 220.97 & 220.55 & 220.16 & 220.04 & 220.36 & 219.87 & 219.87 & 218.26 & 212.80 & 192.61 \\
\hline 0.9 & 216.50 & 216.00 & 215.54 & 215.39 & 215.77 & 215.19 & 215.18 & 213.19 & 212.46 & 191.59 \\
\hline 1.0 & 206.57 & 206.16 & 205.74 & 205.60 & 205.94 & 205.42 & 205.41 & 203.93 & $262.08,260.34$ & 189.98 \\
\hline
\end{tabular}

Figure 2 is given to display the trend of variation of $F_{H}$ with respect to the concentration $(X)$. It can be seen from Figure 2 that the $F_{H}$ is continuously decreasing with respect to concentration $(X)$. The similar type of trend is observed in experimental data [5]. As all correction functions are providing the almost similar results, presently only the result of $\mathrm{H}$-functions are provided in order to avoid overlapping of plots of $F_{H}$.

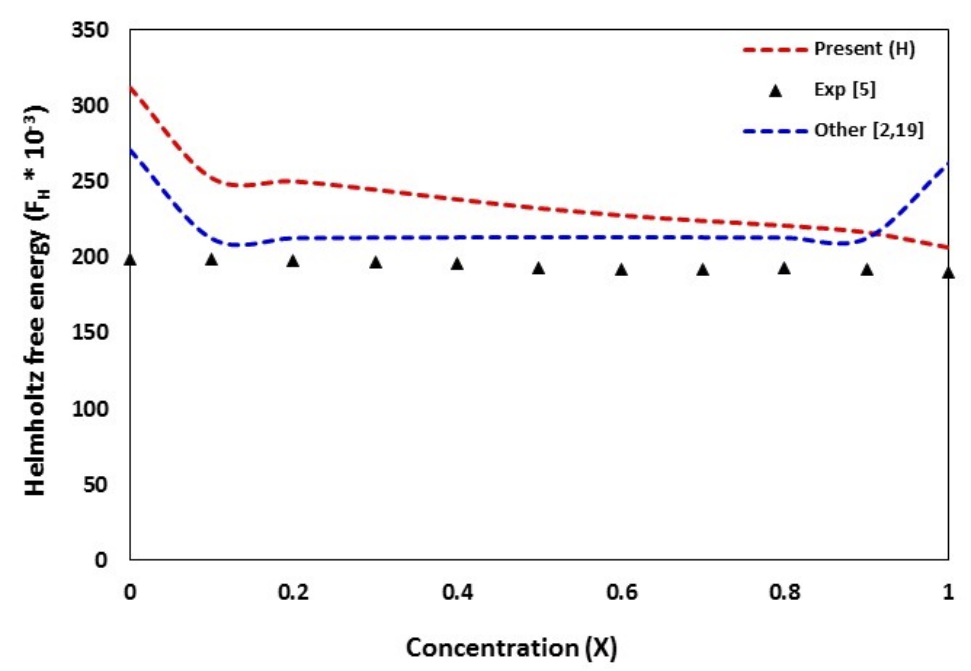

Figure 2. Helmholtz free energy $\left(-F_{H} * 10^{-3}\right)$ au

\section{CONCLUSION}

The variational approach with Gibbs-Bogoliubov inequality [8] is applied for the calculation of thermodynamical properties of liquid $\mathrm{K}_{1-\mathrm{X}} \mathrm{Rb}_{\mathrm{X}}$ alloys. The results for the internal energy $\left(F_{\text {int }}\right)$ and Helmholtz free energy $\left(F_{H}\right)$ at various concentration $(X)$ of participating metals are provided. Good agreement for $F_{H}$ at many higher value of $X$ is obtained between present results and other theoretical results of Vora [2] and Thakor [19] and experimental data [5]. Very less influence of correction function is found and hence the results by various local field correction function generates results very near to each other in the present study.

\section{ORCID IDs}

(D)Rajesh C. Malan, https://orcid.org/0000-0002-6216-8007; (D)Aditya M. Vora, https://orcid.org/0000-0002-2520-0266

\section{REFERENCES}

[1] C. Fiolhais, J.P. Perdew, S.Q. Armster, J.M. MacLaren, and M. Brajczewska, Phys. Rev. B, 51, 14001-14011 (1995), https://doi.org/10.1103/PhysRevB.51.14001.

[2] A.M. Vora, J. Eng. Phys. Thermophys. 82, 779-788 (2009), https://doi.org/10.1007/s10891-009-0250-5.

[3] N. Dubinin, N.A. Vatolin, and V.V. Filippov, Russ. Chem. Rev. 83, 987 (2014), https://doi.org/10.1070/RCR4410. 
[4] I. Umar, A. Meyer, M. Watabe, and W. Young, J. Phys. F Met. Phys. 4, 1691 (1974), https://doi.org/10.1088/0305-4608/4/10/016.

[5] R. Hultgren, P. D. Desai, D. T. Hawkins, M. Gleiser, and K. K. Kelley, Selected Values of the Thermodynamic Properties of Binary Alloys, Am. Soc. Metals, Metal Park, 1973.

[6] R.C. Malan, and A.M. Vora, AIP Conf. Proc. 2009, 020052, (2018), https://doi.org/10.1063/1.5052121.

[7] R.C. Malan, and A.M. Vora, J. Nano-Electronic Phys. 10, 03020 (2018), https://10.21272/jnep.10(1).01002.

[8] A. Isihara, J. Phys. Gen. Phys. 1, 539 (1968), https://doi.org/10.1088/0305-4470/1/5/305.

[9] A.M. Vora, J. Theor. Appl. Phys. 3, 25-32 (2010), https://www.sid.ir/FileServer/JE/134220100405.pdf.

[10] Y. Waseda, The structure of non-crystalline materials: liquids and amorphoussolids, (New York, McGraw-Hill, 1980).

[11] J. Hubbard, Royal Proc. London A, 243, 336-352 (1958), https://doi.org/10.1098/rspa.1958.0003.

[12] L. Sham, Royal Proc. of London A, 283, 33-49 (1965), https://doi.org/10.1098/rspa.1965.0005.

[13] P. Vashishta, and K. Singwi, Phys. Rev. B, 6, 875, (1972), https://doi.org/10.1103/PhysRevB.6.875.

[14] R. Taylor, J. Phys. F Met. Phys. 8, 699 (1978), https://doi.org/10.1088/0305-4608/8/8/011.

[15] A. Sarkar, D. Sen, S. Haldar, and D. Roy, Mod. Phys. Lett. B, 12, 639-648 (1998), https://doi.org/10.1142/S0217984998000755.

[16] S. Ichimaru, and K. Utsumi, Phys. Rev. B, 24, 7385 (1981), https://doi.org/10.1103/PhysRevB.24.7385.

[17] B. Farid, V. Heine, G. Engel, and I. Robertson, Phys. Rev. B, 48, 11602 (1993), https://doi.org/10.1103/PhysRevB.48.11602.

[18] I. Nagy, J. Phys. C Solid State Phys. 19, L481 (1986), https://doi.org/10.1088/0022-3719/19/22/002.

[19] P.B. Thakor, Ph.D. Thesis, Sardar Patel University, V.V. Nagar, Gujarat, India, 2004.

\section{ВАРІАЦІЙНИЙ МЕТОД ТЕРМОДИНАМІКИ РІДКИХ СПЛАВІВ $K_{1-X} R b_{X}$}

Раджеш С. Малан ${ }^{a}$, Адітя М. Вора

${ }^{a}$ Факультет прикладних та гуманітарних наук, Урядовий інженерний коледж, Вальсад-396001, Гуджарат, Індія

${ }^{b}$ Фізичний факультет, Університетська школа наук, Університет Гуджарат, Ахмедабад-380009, Індія

Досліджуються рідкі бінарні сплави $\mathrm{K}_{1-\mathrm{X}} \mathrm{Rb}_{\mathrm{X}}$ з різними термодинамічними пропорціями елементів, що беруть участь. У цій роботі були розраховані внутрішня енергія $\left(F_{\text {int }}\right)$, вільна енергія Гельмгольца $\left(F_{H}\right)$ і ентропія $(S)$ в діапазоні концентрацій від $\mathrm{X}=0.0$ до $X=1.0$, що збільшуються з кроком 0,1 . В дослідження включені властивості термодинамічного характеру. Окрім внутрішньої енергії $\left(\mathrm{F}_{\mathrm{int}}\right)$, в цій статті також розраховуються і окремо відображуються різні вклади в цю енергію. Для цього розрахунку було застосовано варіаційний підхід. Для розрахунку всіх властивостей сплавів використовується єдиний потенціал із набором двох параметрів. Статична функція локального поля Хартрі $(\mathrm{H})$ використовується для урахування ефекту екранування. Для врахування ефекту обміну та кореляції використовуються різні функції локальної корекції поля. Порівняння з експериментальними даними при певній концентрації свідчить про гарний збіг з отриманими на цей час даними. Як показали поточні результати, застосований модельний потенціал виявився дуже придатним для окремих параметрів при термодинамічному дослідженні. Оскільки ці результати забезпечують дані навіть при мінімальній доступності експериментальних висновків, вони можуть служити базою даних для майбутніх розрахунків, які стосуються термодинаміки рідких сплавів. Наведені результати дозволяють отримати властивості, підібрані на основі пропорцій $K_{1-X} R b_{X}$ для різних вимог.

КЛЮЧОВІ СЛОВА: термодинамічні властивості, рідкий лужний сплав, теорія псевдопотенціалу, варіаційний підхід, нерівність Гіббса-Боголюбова 